\title{
Hans-Peter Schultze, a great paleoichthyologist for whom work is synonymous with enjoyment
}

\author{
Richard Cloutier $^{1}$
}

With 4 figures and 2 tables

In the summer of 1982, Hans-Peter Schultze and Gloria Arratia were invited to a small museum located on a fossiliferous site of the Devonian Escuminac Formation in Miguasha, Quebec, eastern Canada. Hans-Peter was to work with Marius Arsenault, the director of the Miguasha Museum, on the skull of the elpistostegalid $E l$ pistostege watsoni, a species closely related to basal tetrapods. In addition, he went through the collections to describe and measure numerous juvenile specimens of the osteolepiform Eusthenopteron foordi. As expected, these two projects turned out to be important contributions in lower vertebrate paleontology and systematics: one on the origin of tetrapods (1985), and the second one on growth patterns of a Late Devonian fish (1984). During his visit to Miguasha, Hans-Peter also spent time digging for fossils and drawing numerous specimens in the collection. In addition, in order to help the personnel of the museum to identify some of the Escuminac fishes, he created an identification key based on the gross morphology of the scales. For a small group of undergraduate students, hired at the museum during the summer as naturalists, it was a unique opportunity to discuss paleontology with a leading researcher. We were amazed by his willingness to talk to us, even if then most of us only spoke French! For the first time, we were exposed to Hennigian methodology and its usage in vertebrate paleontology during an evening lecture that Hans-Peter prepared for us. His lecture was delightful; it was an intensive course in lower vertebrate anatomy, and an intellectual journey among the philosophers Karl Marx and Karl Popper, the entomologists Willy Hennig and Lars Brundin, and "The Band of Four" (Rosen et al. 1981). It was for most of us our first exposure to science, as it should be done. We were all impressed by his knowledge and above all by his simplicity and friendliness. Two years later I started my Ph.D. at The University of Kansas, under the supervision of Hans-Peter.

Compared to his long career, these two weeks that Hans-Peter spent in Miguasha represent an extremely short period of time. Some might say that this little anecdote is insignificant when introducing a vertebrate paleontologist (Fig. 1A) who published 132 papers and books (a total of 2977 published pages) in addition to more than 80 abstracts, book reviews and obituaries. However, this brief story is representative of HansPeter's personality and contributions. $\mathrm{He}$ is a great scientist with numerous interests in science, art, and history. Hans-Peter enjoys digging for fossils, looking at fossils and describing fossils, and he loves sharing his knowledge and experiences with people, independent of their academic training.

\section{Pre-retirement years}

Hans-Peter was born in 1937 in the small coastal town of Swinemünde, in northern Germany (now Poland). His childhood was in a turbulent economic, political and historical period - World War II. Initially, he attended elementary school in Thorn/Westprussia (now Poland) and then in Ernsleben, Harz, which was in the Soviet Zone at that time. In 1949, his mother and four children moved to West-Germany, taking up residence in Offenburg, Baden-Württemberg, where Hans-Peter attended high school, finishing the German "Abitur", in 1956.

From 1956 to 1958, Hans-Peter studied geology at the University of Freiburg im Breisgau, Germany, completing his Diploma (M.Sc.) in geology at the University of Tuibingen in 1962. In 1965, Hans-Peter was awarded a Ph.D. at the

\footnotetext{
1 Département de Biologie, Université du Québec à Rimouski, 300, allée des Ursulines, Rimouski, Québec, Canada.
} 

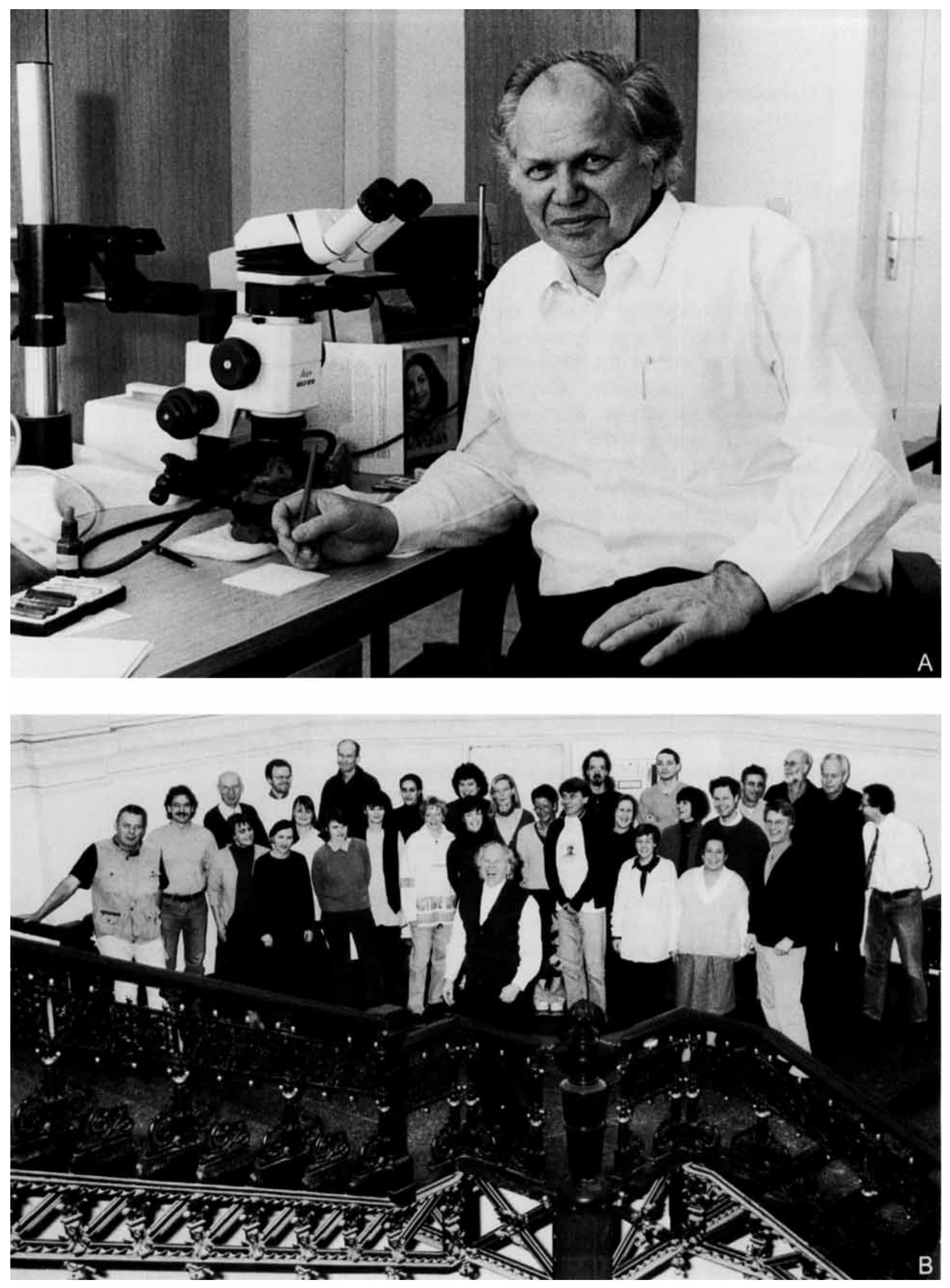

Fig. 1. Hans-Peter Schultze at work in his office in the Institut für Paläontologie der Humboldt University, Berlin, May 2000 (Photo W. Harre) (A), and with the staff of the Institut, Winter 2001 (Photo C. Radke) (B).

Abb. 1. Hans-Peter Schultze in seinem Arbeitszimmer im Institut für Paläontologie der Humboldt Universität zu Berlin, Mai 2000 (Foto W. Harre) (A) und mit den Mitarbeitern des Instituts, Winter 2001 (Foto C. Radke) (B). 
University of Tübingen, for his project on the morphology and histology of Mesozoic actinopterygian scales, a continuation of the work begun by his supervisor Prof. Dr. Walter R. Gross (1935). Gross only accepted two graduate students during his entire career: K. Fahlbusch, in Berlin, and Hans-Peter in Tübingen. As a student of Gross in the early 60 s, Hans-Peter received training on the histology of scales and teeth of Paleozoic and Mesozoic fishes. The results of his $\mathrm{Ph} . \mathrm{D}$. dissertation were published in 1966 , in an impressive and widely cited monograph in which he demonstrated both the evolutionary change from rhombic to round scales in halecostome actinopterygians and the systematic significance of the scales.

From 1965 to 1967, Hans-Peter spent a crucial period of his career at the Naturhistoriska Riksmuseet in Stockholm, Sweden. During this time he worked closely with Erik Jarvik (who was then the director), Erik Stensiö, and Tor Ørvig, a group of paleoichthyologists that eventually came to be referred to as the "Swedish School". At that time, Stockholm was one of the leading centers for paleoichthyology and numerous researchers were trained in the Department of $\mathrm{Pa}$ leozoology. This group of researchers including Hans-Peter, became friends, and have greatly influenced the field of lower vertebrate paleontology during the past 40 years.

From 1967 to 1978, Hans-Peter was at the Geologisch-Paläontologisches Institut und $\mathrm{Mu}-$ seum of the University of Göttingen. During this period, he described material from the collection in Göttingen including placoderms from Iran, collected by Prof. Dr. O. H. Walliser (1973) and the Keuper sauropterygian Nothosaurus. He also collected fossils in the Lower Devonian of Germany. Hans-Peter then spent two years (1970-1971) in the USA as a fellow of the German Academic Exchange Program. During this long journey he visited numerous vertebrate collections throughout the country, drawing an impressive number of specimens and preparing histological acetate peels that later were used in various publications.

In 1970, Hans-Peter took over the editorship of the prestigous Handbook of Paleoichthyology continuing the original work begun by Prof. Dr. O. Kuhn. Since he began his mission as editor, six volumes have been published and Hans-Peter is currently contributing to volumes 1 (Agnatha) and 7 (Sarcopterygii II) and writing volume 6 (Sarcopterygii I: Dipnoi). Critically, Hans-Peter has played an important role in developing the broad scope of the Handbook while maintaining a rigorous framework. Indeed, his tenacity and dedication are crucial to the realisation of this series and many of us are very familiar with that famous line "So, when will you finish your part of the handbook?"

In 1978, Hans-Peter left Germany in order to pursue his career in the USA. Lawrence, Kansas was to become his Land of Oz. He was promoted to the status of Associate Curator in the Division of Vertebrate Paleontology at the Museum of Natural History and Associate Professor for the Department of Systematics and Ecology at the University of Kansas in 1981, and subsequently to Curator and Professor in 1987. From 1988 to 1990, Hans-Peter occupied the position of Chairman for the Department of Systematics and Ecology. During his many years in Lawrence, he invested a great deal of time and energy in expanding the lower vertebrate paleontological collection, increasing collection storage space, cataloguing the collection, and in having the collection computerized. In addition to his teaching and research tasks, in 1990, he organized the $50^{\text {th }}$ Annual meeting of the Society of Vertebrate Paleontology in Lawrence which included a symposium on phylogenetic relationships in vertebrates, the first one in the history of the society.

During his stay in Lawrence, Hans-Peter recruited a dynamic group of graduate students and developed an active research program in lower vertebrate paleontology (Fig. 2). He taught at both undergraduate (e.g., comparative anatomy) and graduate (e.g., lower vertebrate paleontology, structure and evolution of fishes, actinopterygian interrelationships, biology of dinosaurs) levels. His courses (frequently team-taught with Linda Trueb, and occasionally with G. Arratia) were highly valued by the students and considered to be most stimulating and informative. An example of his enthusiasm is worth mentioning. In the spring of 1987, Hans-Peter and Linda were responsible for a graduate seminar series entitled Topics in Evolutionary Morphology. With a tremendous amount of effort they managed to invite a series of prestigious paleontologists (John R. Bolt, Robert L. Carroll, Chang Mee-Mann, Philip J. Currie, James A. Hopson, Nicholas Hotton III, Farrish Jenkins, John H. Ostrom, Alex L. Panchen, Samuel Tarsitano, and Emilia Vorobyeva) to present their ideas and hypotheses on the origins of major groups of vertebrates. As graduate students enrolled in this seminar we were encouraged to question the 


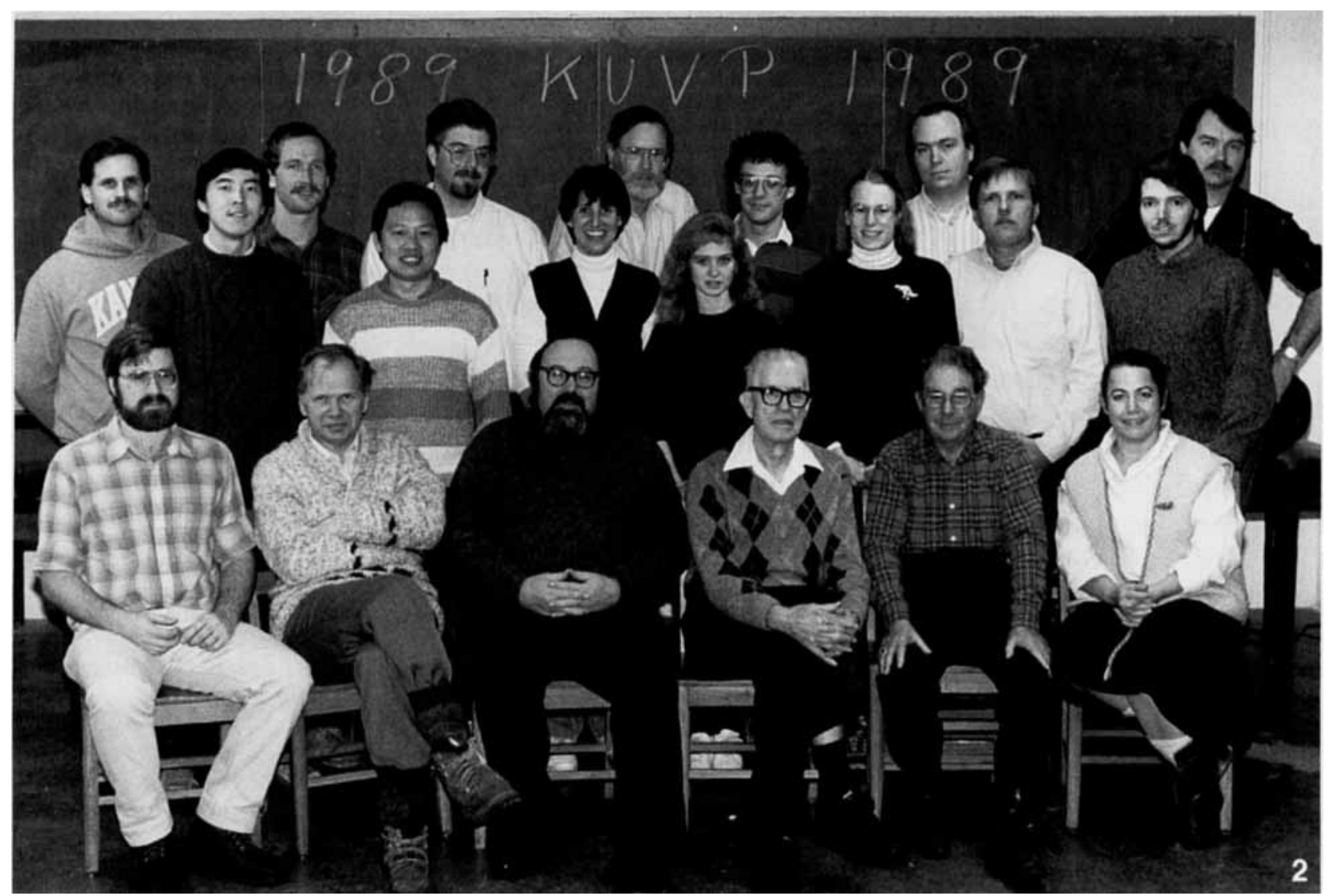

Fig. 2. Hans-Peter Schultze and the staff members and graduate students of the Division of Vertebrate Paleontology, University of Kansas, Lawrence, Winter 1989. From left to right, first row: J. McAllister, H.-P. Schultze, L. Martin, R.W. Wilson, M. Green, and G. Arratia. Second row: X. Wang, D. Miao, J. Herst, C. Westermann, J. Hall, J. Neas, and R. Cloutier. Third row: M. Gottfried, T. Goodwin, C. Cunnigham, J. Chorn, T.J. Meehan, C. Bennet, and B. Foreman.

Abb. 2. Hans-Peter Schultze im Kreise von Mitarbeitern und Studenten der Abteilung Wirbeltierpaläontologie an der Universität Kansas, Lawrence, Winter 1989. Erste Reihe: J. McAllister, H.-P. Schultze, L. Martin, R.W. Wilson, M. Green, und G. Arratia; zweite Reihe: X. Wang, D. Miao, J. Herst, C. Westermann, J. Hall, J. Neas, und R. Cloutier; dritte Reihe: M. Gottfried, T. Goodwin, C. Cunnigham, J. Chorn, T. J. Meehan, C. Bennet, and B. Foreman (jeweils von links nach rechts).

speakers and challenge their ideas, and I remember Hans-Peter sitting among us and smiling during several highly animated discussions. As a result of this exciting adventure the book "Origins of the Higher Groups of Tetrapods. Controversy and Consensus" was published under the co-editorship of Hans-Peter and Linda Trueb in 1991.

After a most fruitful period of 16 years in Lawrence, Hans-Peter took early retirement from the University of Kansas. This "first retirement" was an initial step toward the third major part of his career - a return to Germany. In the summer of 1994, he accepted the directorship of the Institut für Paläontologie at the Museum für Naturkunde in Berlin and was awarded the position of Professor of Paleozoology at the Humboldt-Universität. The Museum für Naturkunde is the largest German natural history museum in the new, as well as the old, capital Berlin. After the reunification of East and West Germany, the Institut für Paläontologie was revitalized by Hans-Peter as director with the help of the staff members. Hans-Peter set himself an ambitious goal, to develop an internationally acclaimed program at the Institute after 45 years of postSecond World War social and economic restrictions. Five years later, he was acting director for the Museum and finally in 2000 was promoted to full director. During his stay in Berlin, Hans-Peter fulfilled his goal in bringing the Institute für Paläontologie to a standard never reached before. Hans-Peter and his collaborators (Fig. 1B) are proud to have diversified their research to include collaborative national and international efforts, to have created professional academic training programs for researchers abroad (in, for example, Argentina, China, Mongolia, Spain, Switzerland), and to have organized national and international meetings, conferences, and special symposia in Berlin and further afield (e.g., Jahrestagung des Arbeitskreises für Paläobotanik und Palynologie; Phylogenetic Symposium; Mesozoic-Cenozoic Bioevents: Possible Links to Impacts and other Causes) all of which have furth- 
ered the study of paleontology. During Hans-Peter's residence, the researchers of the institute have published 369 papers and 224 abstracts in international scientific journals, and seven widely cited books. Furthermore, a new scientific journal - Mitteilungen aus dem Museum für Naturkunde in Berlin, Geowissenschaftliche Reihe was founded and is now well established.

\section{His scientific contribution in a nutshell}

For those of us working on lower vertebrates, Hans-Peter Schultze's contribution is ubiquitous. His papers have been published in more than 70 different scientific journals and books and are cited exhaustively (see the ISI Web of Science). Approximately half of his contributions are coauthored with some 30 different authors of whom Gloria Arratia (10 papers), John Chorn (8 papers) and Chris Maples (5 papers) represent the most productive collaborations. Joint work between H.-P. Schultze and G. Arratia started in 1985 on Late Jurassic teleosts from Northern Chile and Cuba and subsequently led to a series of important contributions on the homology and development of the urohyal (1990), the palatoquadrate (1991), the caudal skeleton $(1986,1988,1989,1992)$, and the ver- tebral column and associated elements (2001, also with Jorge Casciotta). These papers are considered as milestones in the interpretation of morphology and homology in fishes.

Whether it is an invertebrate, a fish, an amphibian, or even a Nothosaurus, Hans-Peter is curious about nature, and has described more than 25 lower vertebrate taxa ranging from acanthodians to sauropterygians (Table 1). Nevertheless, he is primarily interested in the phylogeny and morphology of sarcopterygians and actinopterygians and has published 47 papers dealing with various aspects of lobe finned fishes (the majority of which are highly cited and have strongly influenced our understanding of sarcopterygians and basal actinopterygians). As early as 1970, Hans-Peter was conscious of the possibility of using cladistics to study the origin of tetrapods and his willingness to adopt new perspectives made him one of the first vertebrate paleontologists to use the cladistic method. By examining histological details such as the infolding of the dentine of sarcopterygian teeth, he demonstrated the monophyly of tetrapods and suggested that osteolepiforms were their sister-group. In 1986, he published an important paper that was to start a long debate on the interrelationships of sarcopterygians. Subsequent papers by Hans-Peter on this subject focused on comparisons of

Table 1

Taxa described by Hans-Peter Schultze

\begin{tabular}{|c|c|c|}
\hline Acanthodii & Latviacanthus ventspilsensis Schultze \& Zidek, 1982 & gen. sp. \\
\hline Actinopterygii & Paramicrodon volcanensis Schultze, 1981 & sp. \\
\hline Actinopterygii & Dialipina salgueiroensis Schultze, 1968 & gen. sp. \\
\hline Actinopterygii & Dialipina markae Schultze, 1977 & sp. \\
\hline Palaeonisciformes & Indaginilepis rhombifera Schultze, 1970 & gen. sp. \\
\hline Palaeonisciformes & Ligulalepis toombsi Schultze, 1968 & gen. sp. \\
\hline Palaeonisciformes & Illiniichthys cozarti Schultze \& Bardack, 1987 & gen. sp. \\
\hline Palaeonisciformes & Nozamichthys contorta Schultze \& Bardack, 1987 & gen. sp. \\
\hline Palaeonisciformes & 'Elonichthys' wolffi Schultze \& Bardack, 1987 & sp. \\
\hline Palaeonisciformes & 'Elonichthys' remotus Schultze \& Bardack, 1987 & sp. \\
\hline Semionotiformes & Lepidotes tendaguruensis Arratia \& Schultze, 1999 & sp. \\
\hline Pycnodontiformes & Paramicrodon volcanensis Schultze, 1981 & sp. \\
\hline Teleosteomorpha & Atacamichthys greeni Arratia \& Schultze, 1987 & gen. sp. \\
\hline Teleostei & Domeykos profetaensis Arratia \& Schultze, 1985 & gen. sp. \\
\hline Teleostei & Protoclupea atacamensis Arratia \& Schultze, 1985 & sp. \\
\hline Sarcopterygii & Ventalepis ketleviensis Schultze, 1980 & gen. sp. \\
\hline Dipnoiformes & Westollrhynchus lehmanni (Westoll, 1949) & gen. \\
\hline Dipnoiformes & Iowadipterus halli Schultze, 1992 & gen. sp. \\
\hline Dipnoiformes & Griphognathus sculpta Schultze, 1969 & sp. \\
\hline Dipnoiformes & Megapleuron zangerli Schultze, 1977 & sp. \\
\hline Dipnoiformes & Chirodipterus onawayensis Schultze, 1982 & sp. \\
\hline Actinistia & Miguashaia bureaui Schultze, 1973 & gen. sp. \\
\hline Onychodontida & Grossius aragonensis Schultze, 1973 & gen. sp. \\
\hline Porolepiformes & Quebecius williamsi Schultze, 1973 & gen. sp. \\
\hline Porolepiformes & Holoptychius jarviki Cloutier \& Schultze, 1996 & sp. \\
\hline Porolepiformes & Nasogaluakus chorni Schultze, 2000 & gen. sp. \\
\hline Osteolepiformes & Rhizodopsis hanbuchi Schultze \& Heidtke, 1994 & sp. \\
\hline Amphibia & Euryodus bonneri Schultze \& Foreman, 1981 & $\mathrm{sp}$ \\
\hline Sauropterygia & Nothosaurus edingerae Schultze, 1970 & sp. \\
\hline
\end{tabular}


controversial hypotheses based on reanalyses of a few selected characters (1991), or on phylogenetic analysis of large data matrices (1992, 1994, 1997, 2001). Following the description of the enigmatic Lower Devonian osteichthyan Psarolepis, Hans-Peter and Zhu Min (1997) reinterpreted the phylogeny of sarcopterygians proposed by Cloutier and Ahlberg (1996), suggesting that actinistians, rather than dipnomorphs, were more closely related to tetrapodomorphs, although this hypothesis was to be challenged by the discovery of new material. In 1995 and 1997, Hans-Peter participated in two major field expeditions in the Canadian Arctic with the Canadian Museum of Nature of Ottawa, Canada. Among the material discovered were exceptional specimens of the Early Devonian actinopterygian Dialipina salgueiroensis, a species that Hans-Peter (1968) had described almost 20 years earlier, when it was only known from isolated scales. New phylogenetic analyses including Psarolepis and Dialipina were published recently in order to determine the relationships of basal actinopterygians (Schultze \& Cumbaa 2001) and among basal osteichthyans (Zhu \& Schultze 2001).

Although Hans-Peter shifted from a classical usage of the Hennigian methodology to numerical cladistics in the mid-1980, he remains aware of the importance of proper definition of characters in order to analyze homologous structures. When performing his PAUP analyses on various data sets, he frequently reminds graduate students and colleagues of a comment made by $\mathrm{Da}$ vid Swofford when introducing his program at The University of Kansas, in 1982, "and if you get only one tree, but you cannot explain it biologically - start all over again!" And this is exactly what Hans-Peter is doing.

Hans-Peter is not only interested in the relationships among taxa, but also in the environments in which these organisms lived and evolved. He considers that detailed taphonomic investigations and comparison of total fossil assemblages are the most reliable methods for paleoenvironmental interpretation. The identification of freshwater and marine Paleozoic assemblages and environments have occupied a large part of his interest since 1985 when he first published on marine to onshore vertebrates in the Lower Permian of Kansas. Starting in 1996, Hans-Peter and various collaborators studied Devonian and Carboniferous faunal assemblages using cluster analyses in order to infer paleoenvironment and paleogeography. These statistical methods have often been used in invertebrate paleontology, but are rarely utilised in vertebrate paleontology. Hans-Peter's contributions yielded new interpretations of the Late Devonian Escuminac Formation of Quebec, as a coastal marine environment rather than a freshwater setting, and a lagoonal environment for the Carboniferous tetrapod assemblage of the Hamilton Quarry in Kansas. These new interpretations have initiated a re-evaluation of other Paleozoic localities and assemblages worldwide.

Because of his field experience and interests, Hans-Peter has visited Paleozoic and Mesozoic sites around the world. Among the Devonian sites that he has investigated in more detail is the world famous Escuminac Formation from Quebec. In 1972, he contributed to the field guide for one of the excursions of the International Geological Congress that was held in Montréal, Québec, and subsequently he worked on the majority of the fishes from this locality. In the initial phase of planning of the $7^{\text {th }}$ International Symposium on the Study of Early Vertebrates held in Miguasha in 1991, Hans-Peter and I came up with the idea of editing a volume with the aim of providing an updated interpretation of the geology, paleobiology and paleobotany of the Escuminac Formation. This book, entitled "Devonian Fishes and Plants of Miguasha, Quebec, Canada", with 26 chapters including systematic revisions of all fish species and plants as well as a great deal of information on taphonomy, paleoecology and paleogeography, was published in 1996. Hans-Peter contributed to four chapters including those on a revision of the porolepiforms, Elpistostege, and a paleoenvironmental interpretation of Middle-Late Devonian fish assemblages throughout the world. He did a fantastic job of editing, resulting in a final product that is of superb quality and a fundamental source of information for those working on questions of Paleozoic paleobiology and paleoenvironments.

In 1993, Gloria initiated the symposium "Mesozoic Fishes - Systematics and Paleoecology." Following a successful first meeting in Eichstätt, and the publication in 1996 of the proceedings of this event, a second meeting was held in 1997, at Buckow, near Berlin. Scientific papers resulting from this meeting were compiled in another excellent and widely cited book "Mesozoic Fishes 2 - Systematics and Fossil Record" edited by Gloria and Hans-Peter and published in 1999. 


\section{A field man}

One of Hans-Peter's greatest pleasures is to plan and carry out field work, which has resulted in the collection of much new material for his students research projects and his own research, and the enrichment of museum collections with (thousands of) valuable new specimens. In 1970, he started his Arctic quest with an expedition that he organised with five colleagues and graduate students. This expedition led them to Prince of Wales Island and Ellsemere Island where they collected in the Devonian. In 1995 and 1997, Hans-Peter participated in two major expeditions with a team from the Canadian Museum of Nature, Ottawa, Canada (S. Cumbaa and R. Day) in the Northwest Territories of Canada. While in Lawrence, Hans-Peter organised an impressive number of field seasons including visits to the Lower Devonian of Wyoming, the Middle Devonian of Nevada, the Upper Devonian of central and SW Colorado, the Devonian and Carboniferous of eastern Canada, the Carboniferous of

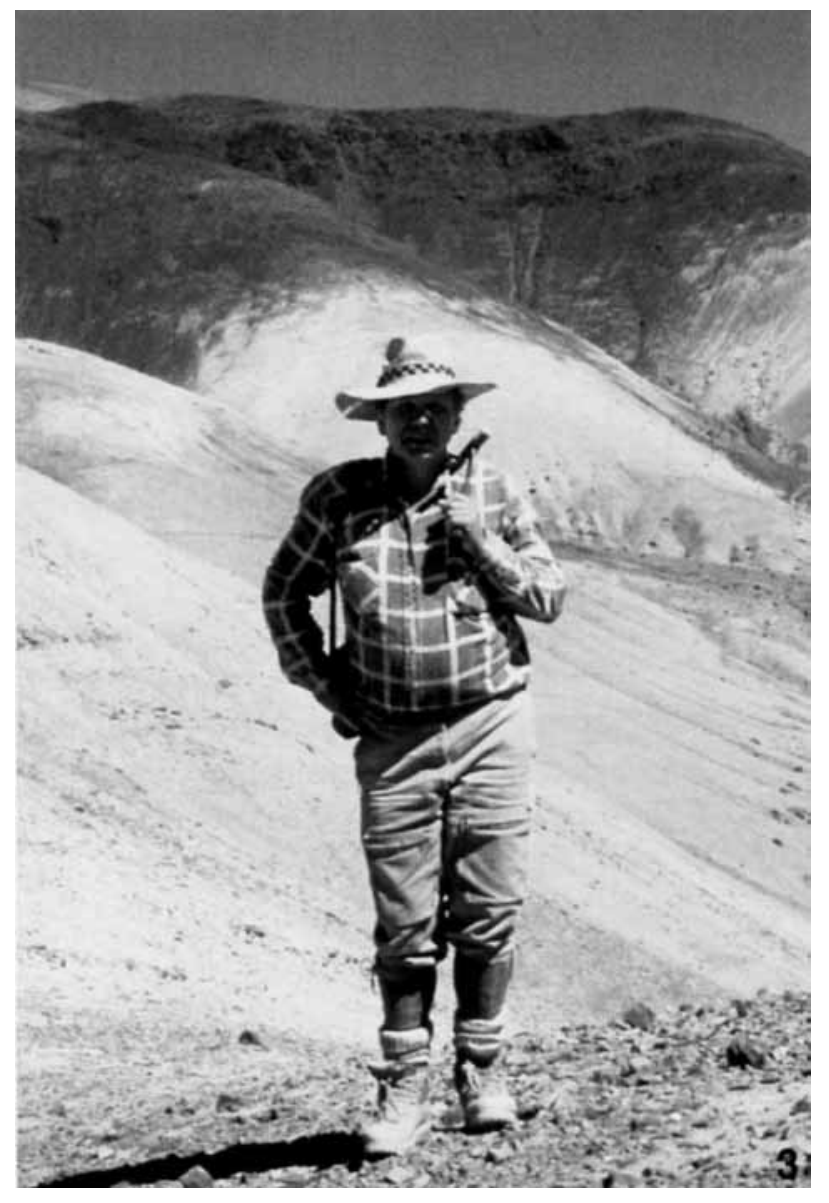

Fig. 3. Hans-Peter Schultze during a field trip in the Atacama Desert in the north of Chile, April 1994.

Abb. 3. Hans-Peter Schultze auf Sammelexkursion in der Atacama-Wüste im Norden Chiles, April 1994.
Kansas and Illinois, and the Permian of Kansas. $\mathrm{He}$ also participated in major expeditions to collect fossils in the Mesozoic of northern Chile (Fig. 3). Most of these field seasons provided Hans-Peter with the opportunity to spend time with his graduate students. Whether it is in the Canadian Arctic or in the middle of a desert in Chile, Hans-Peter is easily recognisable in the field with his "Bavarian trousers" (Fig. 3), his eternal field book, and a bag loaded with fossils.

Indeed, it takes a lot to stop Hans-Peter from going in the field. At the $45^{\text {th }}$ Annual meeting of the Society of Vertebrate Paleontology held in Rapid City, North Dakota, Hans-Peter went collecting fossils on crutches. Not surprisingly, he found more material than most of us (obviously without broken legs) during this afternoon field trip.

\section{A great advisor}

His scientific research, as reflected in his publications, is not the only achievement of Hans-Peter. His contributions to education are also especially valued. During his career, Hans-Peter knew and still knows how to share his love for research. As students, I believe that we first selected Hans-Peter as an advisor because of his impressive contribution to the field of paleontology, his encyclopaedic knowledge of natural sciences, his thorough knowledge of fossil material, and his equally broad knowledge of old and recent literature. Since 1980, Hans-Peter wisely and faithfully supervised ten Ph.D. students (in vertebrates) from different universities in the USA and in Germany, and nineteen postdoctoral research fellows (12-24 month period) from different countries. He has also co-advised numerous masters and doctoral students.

The door of Hans-Peter's office is always wide open, not only during the day, but in the evening and frequently during weekends. Whenever you walk by his office, he is always happy to invite you in and discuss a recently published paper, to look at an enigmatic fossil, or to bounce around some new ideas. He knows how to be present when it is necessary and to give time when it is needed. During the final weeks I spent correcting my dissertation, I remember that Hans-Peter read the newest version of each chapter overnight and not only did he make corrections, but he also carefully checked the coding of large data matrices. The next evenings, over some cheese and cold wine, he would spend hours explaining and discussing his comments. 
For those of us who had the privilege to have Hans-Peter as our advisor, he was not only a scientific figure, but our confidant and friend. After having married Gloria twice (because of political and bureaucratic differences between the USA and Chile) he assisted some of us with our own weddings, even if sometimes it required travelling half way around the world.

In summary, Hans-Peter possesses all the qualities of a great mentor; he likes sharing his knowledge, provides judicious advice, and knows when it is time for his students to leave the "nest."

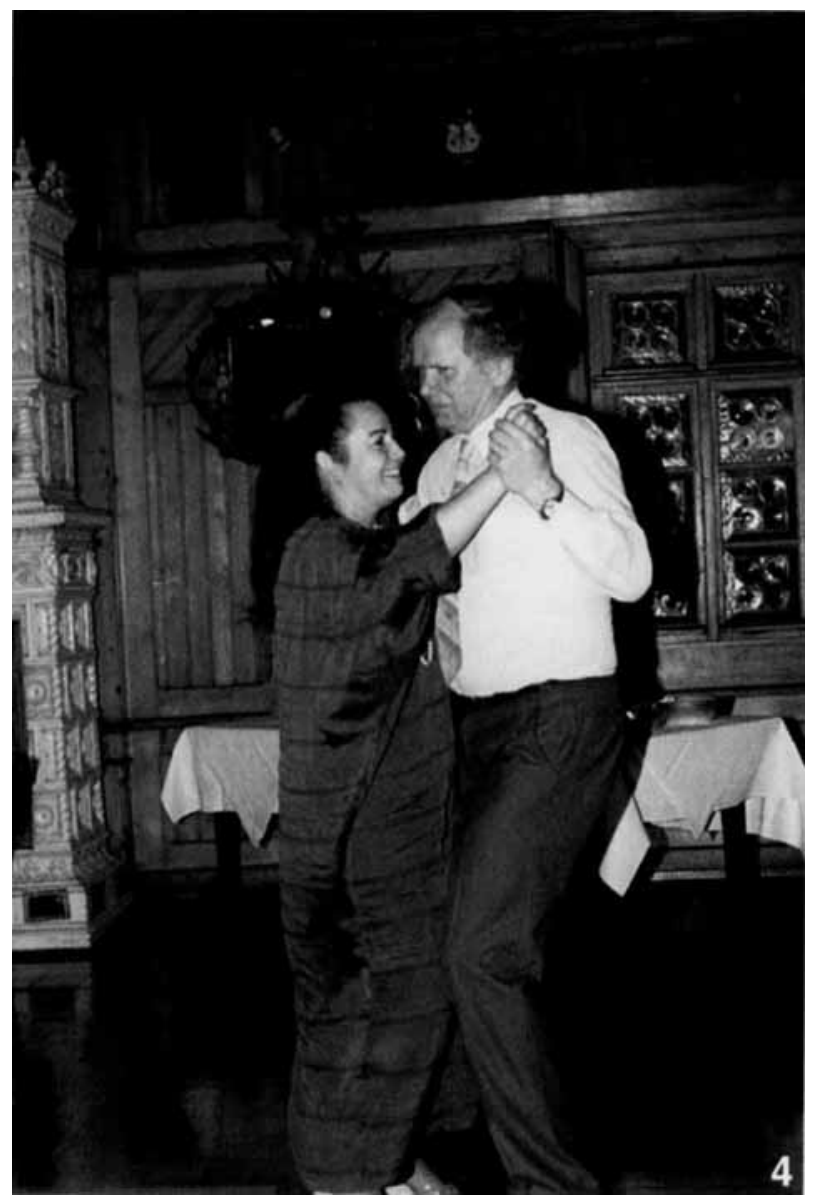

Fig. 4. Gloria Arratia and Hans-Peter Schultze waltzing, Black Forest, Summer 1991.

Abb. 4. Gloria Arratia und Hans-Peter Schultze beim Tanz, Schwarzwald, Sommer 1991.

\section{A man who enjoys life}

Beyond his scientific contributions, Hans-Peter is a man who enjoys life and friends. $\mathrm{He}$ is not only a great man of science, but also a great man for people. Besides paleontology, Hans-Peter likes the outdoors (hiking in the Rockies), gardening (around the Kansas house he renovated years ago), visiting cultural and historical sites (it is always an enlightening event to travel around the world with him), collecting art, masks, and stamps (recently he even published a paper with Oliver Hampe on stamps illustrating fossil fishes), listening to classical music (nothing like the pop, or alternative music that Gloria enjoys so much), ballroom dancing (Fig. 4), and above all social gatherings. Hans-Peter loves to invite people to his place, and to organize receptions for graduate students, colleagues, visiting scientists and friends. There is always a good reason to get together to share some cheese, cold cuts and a bottle of white wine (even though he is German, Hans-Peter does not drink beer). Every year for Christmas, Hans-Peter and Gloria organized a party for paleontologists, a tradition started in Lawrence and kept up in Berlin. One of the high points of this celebration is the Feuerzangenbowle. This holiday tradition comes to life when Hans-Peter lights a rum drenched sugar cone that melts in a mixture of red wine, orange juice, and spices. It is worth being a paleontologist simply to enjoy the harmony of this beverage.

Hans-Peter Schultze has and continues to contribute greatly to our understanding of lower vertebrate systematics and morphology. Indeed, several authors have recognized his important contributions by naming species in his honour (Table 2) including two more new species described in this volume, and I am convinced that Hans-Peter's second retirement is only the beginning of another productive period that our field will remember for centuries.

Table 2

Taxa described in honour to Hans-Peter Schultze

Ellesmereia schultzei Vieth, 1980

Unarkaspis schultzei Elliott, 1983

Platysomus schuitzei Zidek, 1992

Adelargo schultzei Johanson \& Ritchie, 2000

Soleidarum schultzei Nolf \& Lapierre, 1979

Spinoaequalis schultzei deBraga \& Reisz, 1995
Lower Devonian

Lower Devonian

Upper Carboniferous

Upper Devonian

Eocene

Carboniferous
Canada

Canada

USA

Australia

France

USA 


\section{Acknowledgements}

The editors gave me the opportunity to write this paper on a great man of science and a good friend, Hans-Peter. Gloria Arratia provided valuable assistance with biographical details, David Unwin improved the English of earlier versions, and Mrs. Elke Siebert helped with the illustrations.

\section{Literature}

Cloutier, R. \& Ahlberg, P. E. 1996. Morphology, characters, and the interrelationships of basal sarcopterygians. In Stiassny, M. L. J., Parenti, L. R. \& Johnson, G. D. (eds). Interrelationships of Fishes: 445-479. Academic Press, New York.

deBraga, M. \& Reisz, R. R. 1995. A new diapsid reptile from the Uppermost Carboniferous (Stephanian) of Kansas. - Palaeontology 38: 199-212.

Elliott, D. K. 1983. New Pteraspididae (Agnatha, Heterostraci) from the Lower Devonian of Northwest Territories, Canada. - Journal of Vertebrate Paleontology 2 (4): $389-406$
Gross, W. R. 1935. Histologische Untersuchungen am Aussenskelett fossiler Agnathen und Fische. - Palaeontographica A 83: 1-60.

Johanson, Z. \& Ritchie, A. 2000. A new Late Famennian lungfish from New South Wales, Australia, and its bearing on Australian-Asian terrane relations. - Alcheringa 24: 99-118.

Nolf, D. \& Lapierre, H. 1979. Otolithes de Poissons nouveaux ou peu connus du Calcaire Grossier et de la Formation d'Auvers (Éocène du Bassin parisien). Bulletin, Muséum National d'Histoire naturelle, Paris, $4^{\mathrm{e}}$ série, $\mathbf{1}$, section C (2): 79-125.

Rosen, D. E., Forey, P. L., Gardiner, B. G. \& Patterson, C. 1981. Lungfishes, tetrapods, paleontology, and plesiomorphy. - Bulletin of the American Museum of Natural History 167: $159-276$.

Vieth, J. 1980. Tholodontier-, Acanthodier-, und Elasmobranchier-Schuppen aus dem Unter-Devon der Kanadischen Arktis (Agnatha, Pisces). - Göttinger Arbeiten zur Geologie und Paläontologie 23: 1-69.

Zidek, J. 1992. Late Pennsylvanian Chondrichthyes, Acanthodii, and deep-bodied Actinopterygii from the Kinney Quarry, Manzanita Mountains, New Mexico. - New Mexico Bureau of Mines and Mineral Resources Bulletin 138: $145-182$.

\section{Hans-Peter Schultze's Bibliography}

(Abstracts are excluded)

1966. Morphologische und histologische Untersuchungen an Schuppen mesozoischer Actinopterygier (Uebergang von Ganoid- zu Rundschuppen). - Neues Jahrbuch für Geologie und Paläontologie, Abhandlungen 126 (3): 232-314.

1968. Palaeoniscoidea-Schuppen aus dem Unterdevon Australiens und Kanadas und aus dem Mitteldevon Spitzbergens. Bulletin of the British Museum (Natural History), Geology 16 (7): 343-368.

1969. Griphognathus GROSS, ein langschnauziger Dipnoer aus dem Oberdevon von Bergisch-Gladbach (Rheinisches Schiefergebirge) und von Lettland. - Geologica et Palaeontologica 3: 21-79.

1969. Die Faltenzähne der rhipidistiiden Crossopterygier, der Tetrapoden und der Actinopterygier-Gattung Lepisosteus; nebst einer Beschreibung der Zahnstruktur von Onychodus (struniiformer Crossopterygier). - Palaeontographica Italica 65 (new serie 35): $63-137$.

1970. Ein Nothosauride aus dem unteren Mittel-Keuper Unterfrankens. - Göttinger Arbeiten zur Geologie und Paläontologie 5, H. Martin Festschrift: $101-112$.

1970. Folded teeth and the monophyletic origin of tetrapods. - American Museum Novitates No. 2408: 1-10.

1970. Indaginilepis rhombifera n. gen. et n. sp., ein altertümlicher Palaeoniscoide (Pisces, Actinopterygii) aus dem Wealden von Norddeutschland. - Paläontologische Zeitschrift 44: 10-24.

1970. Die Histologie der Wirbelkörper der Dipnoer. - Neues Jahrbuch für Geologie und Paläontologie, Abhandlungen 135 (3): 311-336.

1970. Ueber Nothosaurus. Neubeschreibung eines Schädels aus dem Keuper. - Senckenbergiana Lethaea 51: 211-237.

1971. Ergänzungen zu "Mineralien des Kinzigtales" von H. Kupferer (Die Ortenau 49, 1969). - Die Ortenau 51: $238-240$.

1972. Early growth stages in coelacanth fishes. - Nature, New Biology 236 (64): 90-91.

1972. Homalacanthus, ein oberdevonischer Acanthodier mit Haifisch-ähnlichen Zähnen. - Neues Jahrbuch für Geologie und Paläontologie, Monatshefte 1972: 312-317.

1972. New fossils from the lower Upper Devonian of Miguasha. In Carroll, R. L., Belt, E. S., Dineley, D. L., Baird, D. \& McGregor, D. C. Vertebrate Paleontology of Eastern Canada. - International Geological Congress 24. session, Montreal, Field Excursion A 59: 94.

1972. Die Wirbeltiere des Erdaltertums. In Heberer, G. \& Wendt, H. (Hrsg.). Entwicklungsgeschichte der Lebewesen. Ergänzungsband zu GRZIMEKs Tierleben: 231-251. Kindler Verlag, Zürich.

1973. Crossopterygier mit heterozerker Schwanzflosse aus dem Oberdevon Kanadas, nebst einer Beschreibung von Onychodontida-Resten aus dem Mitteldevon Spaniens und aus dem Karbon der USA. - Palaeontographica A 143: 188-208.

1973. Large Upper Devonian Arthrodires from Iran. - Fieldiana, Geology 23: 53-78.

1974. Osteolepidide Rhipidistia (Pisces) aus dem Pennsylvanian von Illinois/USA. - Neues Jahrbuch für Geologie und Paläontologie, Abhandlungen 146: 29-50.

1974. (Obituary of:) Nachruf auf Walter Robert Gross. - Paläontologische Zeitschrift 48: 143-148.

1974. (Obituary of:) Walter Robert Gross 1903-1974. - Society of Vertebrate Paleontology, News Bulletin No. $102: 47$.

1974. Die Lungenfisch-Gattung Conchopoma (Pisces, Dipnoi). - Senckenbergiana Lethaea 56: 191-231.

1974. Nomenklatorischer Kurzbericht. Gutachtliche Entscheidungen des ICZN (Vertebrata). Bulletin of Zoological Nomenclature 18-22, 1960-1966. - Paläontologische Zeitschrift 48: 140.

1975. Das Axialskelett der Dipnoer aus dem Oberdevon von Bergisch-Gladbach (Westdeutschland). - Colloques internationaux C.N.R.S., Nr. 218, Problèmes actuels de Paléontologie - Evolution des Vertébrés: 149-157.

1975. (Review of:) Jessen, Hans L.: Schultergürtel und Pectoralflosse bei Actinopterygiern. - Fossils and Strata 1: 1-101. Zentralblatt für Geologie und Paläontologie 1975, II: 163-164.

1976. Addendum. In SCHMIDT, Wo. (1976): Der rest eines actinolepididen placodermen (pisces) aus der bohrung bolland (Emsium, Belgien). - Mémoires pour servir à l'explication des cartes géologiques et minières de la Belgique, no. 14: 19-21. 
1976. Paleozoic vertebrates. In Grzimek's Encyclopedia of Evolution: 217-238. Van Nostrand Reinhold Co., New York.

1977. Megapleuron zangerli. A new dipnoan from the Pennsylvanian, Illinois. - Fieldiana, Geology 33: 375-396.

1977. The origin of the tetrapod limb within the rhipidistian fishes. In Hecht, M. K., Goody, P. C. \& Hecht, B. M. (eds). Major Patterns in Vertebrate Evolution. NATO Advanced Study Institute Series, Serie A: Life Science A14: 541-544. Plenum Press, New York \& London.

1977. Ausgangsform und Entwicklung der rhombischen Schuppen der Osteichthyes (Pisces). - Paläontologische Zeitschrift 51: $152-168$.

1980. Eier legende und lebend gebärende Quastenflosser. - Natur und Museum 110 (4): 101-108.

1980. Crossopterygier-Schuppen aus dem obersten Oberdevon Lettlands (Osteichthyes, Pisces). - Neues Jahrbuch für Geologie und Paläontologie, Monatshefte 1980: 215-228.

1980. Egg-laying and Live-bearing Lobe-finned Fishes. Translation of "Eier legende..." Natur und Museum 110: 101-108; 1980. - Private circulation, Department of Geology, Field Museum of Natural History, Chicago.

1980. (Review of:) The Biology and Physiology of the Living Coelacanth. In McCosker, J. E. \& Lagios, M. D. (eds). 1979. Occasional Papers of the California Academy of Sciences, No. 134. - Systematic Zoology 29 (2): 226-228.

1981. Chirodipterus, the first lungfish from the Middle Devonian of Michigan. - The Town Meeting (Serving Elk Rapids and Surrounding Community) 7 (14): 4.

1981. Hennig und der Ursprung der Tetrapoda. - Paläontologische Zeitschrift 55: 71-86.

1981. A new gymnarthrid microsaur from the Lower Permian of Kansas, USA, with a review of the tuditanomorph microsaurs (Amphibia). - Occasional Papers of the Museum of Natural History, University of Kansas 91: 1-25. (With B. Foreman)

1981. Das Schädeldach eines ceratodontiden Lungenfisches aus der Trias Süddeutschlands (Dipnoi, Pisces). - Stuttgarter Beiträge für Naturkunde, Serie B (Geologie und Paläontologie) 70: 1-31.

1981. A pycnodont dentition (Paramicrodon volcanensis $\mathrm{n}$. sp.; Pisces, Actinopterygii) from the Lower Cretaceous of El Volcán region, southeast of Santiago, Chile. - Revista Geológica de Chile 12: 87-93.

1981. A dipnoan tooth plate from the Lower Cretaceous of Kansas, USA. - Transactions of the Kansas Academy of Sciences 84 (4): $187-195$.

1981. Vertebrate paleontology. - Geotimes 26 (2): 56-57. (With M. C. McKenna \& J. A. Hopson)

1981. Tetrapod Origins. (Review of:) The Terrestrial Environment and the Origin of Land Vertebrates. A. L. Panchen, Ed. New York, 1980. - Science 212: 657-658.

1981. (Review of:) Basic Structure and Evolution of Vertebrates by Erik Jarvik. Volume 1, 1980. XVL + 576 pp. Volume 2, 1981. XLL + 338 pp. Academic Press, London, New York. - Journal of Vertebrate Paleontology 1 (3-4): 389-397. (With L. Trueb)

1982. Ein primitiver Acanthodier (Pisces) aus dem Unterdevon Lettlands. - Paläontologische Zeitschrift 56 (1/2): $95-105$. (With J. Zidek)

1982. A dipterid dipnoan from the Middle Devonian of Michigan, U.S.A. - Journal of Vertebrate Paleontology 2 (2): $155-162$.

1982. Type and Figured Specimens of Fossil Vertebrates in the Collection of the University of Kansas Museum of Natural History. Part I. Fossil Fishes. - Miscellaneous Publication No. 73, University of Kansas, Museum of Natural History: 1-53. (With J. D. Stewart, A. M. Neuner \& R. W. Coldiron)

1982. Vertebrate paleontology. - Geotimes 27 (2): 56-57. (With M. McKenna)

1983. A labyrinthodont palatine from the Permian of Fort Sill, Oklahoma, reinterpreted as a vomer. - Journal of Paleontology 57: $1050-1052$. (With J. Chorn)

1983. Middle Jurassic age of the fish-bearing horizon in the Cañon City embayment, Colorado. - Journal of Paleontology 57: 1053-1060. (With G. Enciso)

1984. The neopterygian Amia as a living fossil. In Eldredge, N. \& Stanley S. M., (eds). Living Fossils: 153-159. Springer Verlag, New York. (With E. O. Wiley)

1984. Family Lepisosteidae (gars) as living fossils. In Eldredge. N. \& Stanley, S. M., (eds). Living Fossils: 160-165. Springer Verlag, New York. (With E. O. Wiley)

1984. Juvenile specimens of Eusthenopteron foordi Whiteaves, 1881 (Osteolepiform Rhipidistian, Pisces) from the Upper Devonian of Miguasha, Quebec, Canada. - Journal of Vertebrate Paleontology 4 (1): 1-16.

1984. The head shield of Tiaraspis subtilis (GROSS) [Pisces, Arthrodira]. - Proceedings of the Linnean Society of New South Wales 107 (3): $355-366$.

1984. Vertebrate paleontology. - Geotimes 29 (2): 14-16. (With R. J. Emry)

1985. Reproduction and spawning sites of Rhabdoderma (Pisces, Osteichthyes, Actinistia) in Pennsylvanian deposits of Illinois, USA. - Compte Rendu, Neuvième Congrès International de Stratigraphie et de Géologie du Carbonifère, vol. 5 : 326-330. Carbondale and Edwardsville, Illinois.

1985. The panderichthyid fish Elpistostege a close relative of tetrapods? - Palaeontology 28 (2): 293-309. (With M. Arsenault)

1985. Late Jurassic teleosts (Actinopterygii, Pisces) from Northern Chile and Cuba. - Palaeontographica A 189: 29-61. (With G. Arratia)

1985. Marine to onshore vertebrates in the Lower Permian of Kansas and their paleoenvironmental implications. - University of Kansas Paleontological Contribution, Paper 113: 1-18.

1985. Type and Figured Specimens of Fossil Vertebrates in the Collection of the University of Kansas Museum of Natural History. Part II. Fossil Amphibians and Reptiles. - Miscellaneous Publication No. 77, University of Kansas, Museum of Natural History:1-6. (With L. Hunt, J. Chorn \& A. M. Neuner)

1986. Rhizodopside Rhipidistia (Pisces) aus dem Perm der Pfalz (W-Deutschland). - Neues Jahrbuch für Geologie und Paläontologie, Monatshefte 1986, H.3: 165-170. (With U. Heidtke)

1986. Palaeoniscoid (Actinopterygii, Pisces) vertebrae from the Late Paleozoic of Central North America. - Journal of Paleontology 60 (3): 744-757. (With J. Chorn)

1986. Wirbeltierreste aus dem Mittleren Muschelkalk (Trias) von Göttingen, West-Deutschland. - Paläontologische Zeitschrift 60 (1/2): 109-129. (With H. Möller)

1986. Reevaluation of the caudal skeleton of actinopterygian fishes. I. Lepisosteus and Amia. - Journal of Morphology 190: 215-241. (With G. Arratia) 
1986. Vertebrate paleontology. - Geotimes 31 (2): 57-59. (With R. J. Emry)

1986. (Obituary of:) Robert H. Denison, 1911-1985. - Society of Vertebrate Paleontology, News Bulletin 136: 59-61. (With R. Zangerl)

1986. (Review of:) Three books on Permian vertebrates from Germany. - Journal of Vertebrate Paleontology 6 (2): 206-208.

1987. Characterization of the Dipnoi, a monophyletic group. - Journal of Morphology, Supplement 1: 25-37. (With K. S. W. Campbell)

1987. Dipnoans as sarcopterygians. - Journal of Morphology, Supplement 1: 39-74.

1987. Diversity and size changes in palaeonisciform fishes (Actinopterygii, Pisces) from the Pennsylvanian of the Mazon Creek fauna, Illinois, USA. - Journal of Vertebrate Paleontology 7 (1): 1-23. (With D. Bardack)

1987. A new halecostome fish (Actinopterygii, Osteichthyes) from the Late Jurassic of Chile and its relationships. - Dakoterra 3: 1-13. (With G. Arratia)

1987. Elasmobranchier-Reste aus dem Unterkarbon des Rheinischen Schiefergebirges und des Harzes (W-Deutschland). Neues Jahrbuch für Geologie und Paläontologie, Abhandlungen 175 (3): 317-346. (With H. Mader)

1987. Quebecius quebecensis (Whiteaves), a porolepiform crossopterygian (Pisces) from the Late Devonian of Quebec, Canada. - Canadian Journal of Earth Science 24 (12): 2351-2361. (With M. Arsenault)

1987. Vertebrate paleontology. - Geotimes 32 (2): 57-59. (With K. Padian \& D. W. Krause)

1988. Reevaluation of the caudal skeleton of some actinopterygian fishes. II. Hiodon, Elops and Albula. - Journal of Morphology 195: 257-303. (With G. Arratia)

1988. Recent radiological imaging techniques for morphological studies of Latimeria chalumnae. - Environmental Biology of Fishes 23 (4): 7-8. (With R. Cloutier, E. O. Wiley, J. A. Musick, J. C. Daimler, M. A. Brown, S. J. Dwyer III, L. T. Cook \& R. L. Laws)

1988. Notes on the structure and phylogeny of vertebrate otoliths. - Copeia 1988 (1): 257-260.

1989. The Upper Pennsylvanian vertebrate fauna of Hamilton, Kansas. In Mapes, G. \& Mapes, R. H. (eds). Regional Geology and Paleontology of Upper Paleozoic Hamilton Quarry Area in southeastern Kansas. - Kansas Geological Survey, Guidebook Series 6: 147-154. (With J. Chorn)

1989. An osteolepidid rhipidistian in Upper Pennsylvanian deposits of Hamilton, Kansas. In Mapes, G. \& Mapes, R. H. (eds). Regional Geology and Paleontology of Upper Paleozoic Hamilton Quarry Area in southeastern Kansas. - Kansas Geological Survey, Guidebook Series 6: 181-183.

1989. A complete specimen of Sagenodus (Dipnoi) from the Upper Pennsylvanian of the Hamilton Quarry, Kansas. In Mapes, G. \& Mapes, R. H. (eds). Regional Geology and Paleontology of Upper Paleozoic Hamilton Quarry Area in southeastern Kansas. - Kansas Geological Survey, Guidebook Series 6: 173-176. (With J. Chorn)

1989. A preliminary comparison of the Pennsylvanian assemblage of Hamilton, Kansas, with marine and nonmarine contemporaneous assemblages. In Mapes, G. \& Mapes, R. H. (eds). Regional Geology and Paleontology of Upper Paleozoic Hamilton Quarry Area in southeastern Kansas. - Kansas Geological Survey, Guidebook Series 6: 253-273. (With C. G. Maples)

1989. X-radiographic techniques and applications. In Feldman, R. M., Chapman, R. \& Hannibal, J. T. (eds). Paleotechniques. - Paleontological Society, Special Publication No. 4: 165-177. (With R. Zangerl)

1989. The composition of the caudal skeleton of teleosts (Actinopterygii, Osteichthyes). - Zoological Journal of the Linnean Society, London 97: 189-231. (With G. Arratia)

1989. Three-dimensional muscle preservation in Jurassic fishes of Chile.- Revista Geológica de Chile 16 (2):183-215.

1989. Vertebrate paleontology. - Geotimes 34 (2): 46-47. (With R. W. Graham, J. Gauthier \& D. Prothero)

1989. (Field guide:) The Hamilton Quarries. In Pabian R. K. \& Diffendal, R. F. Jr. (eds). Late Pennsylvanian and Early Permian Cyclic Sedimentation, Paleogeography, Paleoecology, and Biostratigraphy in Kansas and Nebraska. Guidebook, Annual Meeting of the Geological Society of America, St. Louis, Missouri: 34-35. - Nebraska Geological Survey, Lincoln, Nebraska. (With R. H. Mapes \& C. G. Maples)

1990. The urohyal: Development and homology within osteichthyans. - Journal of Morphology 203 (3): 247-282. (With G. Arratia)

1990. A new acanthodian from the Pennsylvanian of Utah, U.S.A., and the distribution of otoliths in gnathostomes. - Journal of Vertebrate Paleontology 10 (1): 49-58.

1990. (Biography of:) GROSS, WALTER ROBERT (b. Katlakaln near Riga, Latvia, Russia, 20 August 1903; d. Tübingen, Germany, 9 June 1974), vertebrate paleontology. - Dictionary of Scientific Biography, Vol. 17, Supplement II: 369-371.

1990. (Field guide:) The Robinson locality; fauna and depositional environment. In Cunningham, C. R. \& Maples, C. G. (eds). 1990 Society of Vertebrate Paleontology; Upper Paleozoic of Eastern Kansas; Excursion Guidebook. - Kansas Geological Survey, Open-file Report 90-24: 17-24. (With J. Chorn)

1990. Vertebrate paleontology. - Geotimes 35 (2): 45-46. (With J. Gauthier, D. Prothero \& R. Cloutier)

1990. Tertiary Fossil-Lagerstätten in Germany. - Journal of Vertebrate Paleontology 10 (2): 270-272.

1991. Palatoquadrate and its ossifications: Development and homology within osteichthyans. - Journal of Morphology 208: 1-81. (With G. Arratia)

1991. Computed tomography and magnetic resonance imaging studies of Latimeria chalumnae. - Environmental Biology of Fishes 32: 159-181. (With R. Cloutier)

1991. CT scan reconstruction of the palatal region of Latimeria chalumnae. - Environmental Biology of Fishes 32: 183-192.

1991. A comparison of controversial hypotheses on the origin of tetrapods. In Schultze, H.-P. \& Trueb, L. (eds). Origins of Major Groups of Tetrapods. Controversy and Consensus: 29-67. Cornell University Press, Ithaca, New York.

1991. Panderichthyid fishes and the origin of tetrapods. In Schultze, H.-P. \& Trueb, L. (eds). Origin of Major Groups of Tetrapods. Controversy and Consensus: 68-109. Cornell University Press, Ithaca, New York. (With E. Vorobyeva)

1991. Der Ursprung der Tetrapoden - ein lebhaft diskutiertes altes Problem. - Verhandlungen der Deutschen Zoologischen Gesellschaft 84: 135-151.

1992. A new long-headed dipnoan (Osteichthyes, Pisces) from the Middle Devonian of Iowa, USA. - Journal of Vertebrate Paleontology 12 (1): 42-58.

1992. Coelacanth fish (Actinistia, Sarcopterygii) from Late Pennsylvanian of Kinney Brick Company Quarry, New Mexico. New Mexico Bureau of Mines \& Mineral Resources, Bulletin 138: 205-209. 
1992. Comparison of the Late Pennsylvanian faunal assemblage of Kinney Brick Company Quarry, New Mexico, with other Late Pennsylvanian Lagerstätten. - New Mexico Bureau of Mines \& Mineral Resources, Bulletin 138: 231-242. (With C. G. Maples)

1992. Relative importance of molecular, neontological and paleontological data in understanding the biology of the vertebrate invasion of land. - Journal of Molecular Evolution 35: 93-101. (With C. Marshall)

1992. Lungfish from the El Molino Formation (Late Cretaceous) and Santa Lucia (Early Paleocene) Formations in Southcentral Bolivia. In Suárez-Soruco, R. (ed.). Fósiles y Facies de Bolivia - Vol. I. Vertebrados. - Revista Técnica de Yacimientos Petrolíferos Fiscales Bolivianos 12 (3-4): 441-448. Santa Cruz.

1992. Pycnodont fish (Actinopterygii, Osteichthyes) from the El Molino Formation (Late Cretaceous to Early Paleocene) of Bolivia. In Suárez-Soruco, R. (ed.). Fósiles y Facies de Bolivia - Vol. I. Vertebrados. - Revista Técnica de Yacimientos Petrolíferos Fiscales Bolivianos 12 (3-4): 449-452. Santa Cruz.

1992. Reevaluation of the caudal skeleton of certain actinopterygian fishes: III. Salmonidae. Homologization of caudal skeletal structures. - Journal of Morphology 214: 187-249. (With G. Arratia)

1992. Early Devonian actinopterygians (Osteichthyes, Pisces) from Siberia. In Mark-Kurik, E. (ed.). Fossil Fishes as Living Animals. - Academia 1: 233-242. Tallinn, Estonia.

1992. (Review of:) FOSSILIEN ATLAS FISCHE, by Karl Albert Frickhinger. Mergus, Verlag für Natur- und Heimtierkunde, Melle, Germany. - Journal of Vertebrate Paleontology 12 (1):128-129.

1992. (Review of:) K. A. Frickhinger: Fossilien Atlas Fische. Mergus, Verlag für Natur- und Heimtierkunde. Melle 1991. 1088 S., 1500, meist farbige Abb., DM 128. - Naturwissenschaftliche Rundschau 5/1992: 206-207.

1993. Pattern of Diversity in the Skull of Jawed Fishes. In Hanken, J, \& Hall, B. K. (eds). The Skull, Vol. 2: Patterns of Structural and Systematic Diversity: 189-254. University of Chicago Press, Chicago/London.

1993. Contrasting the use of functional complexes and isolated characters in lungfish evolution. - Memoirs of the Association of Australasian Palaeontologists 15: 211-224. (With C. R. Marshall.)

1993. (Field guide:) The Garnett and Hamilton paleovalleys, and their relationship to the Douglas Group paleovalleys. In Archer, A. W., Feldman, H. R. \& Lanier, W. P. (eds). Incised Paleovalleys of the Douglas Group in Northeastern Kansas: Field Guide and Related Contributions. - Kansas Geological Survey, Open-File Repport 93-24: 12-1-12-10. (With H. R. Feldman, A. W. Arche, R. R. West, C. G. Maples, C. R. Cunningham \& W. P. Lanier)

1993. Osteichthyes: Sarcopterygii. In Benton, M. J. (ed.). The Fossil Record 2: 657-663. Chapman \& Hall, London.

1993. The Upper Carboniferous (Stephanian) Hamilton Fossil-Lagerstätte in Kansas: a valley-fill, tidally influenced deposit. Lethaia 26: 225-236. (With C. R. Cunningham, H. R. Feldman, E. K. Franseen, R. A. Gestaldo, G. Mapes \& C. G. Maples)

1994. The Hamilton Konservat-Lagerstätte: Stephanian terrestrial biota in a marginal-marine setting. - Transactions of the Royal Society of Edinburgh: Earth Science 84 (3/4): 443-451. (With C. G. Maples \& C. R. Cunningham)

1994. Comparison of hypotheses on the relationships of sarcopterygians. - Systematic Biology 43 (2): 155-173.

1994. Palaeophichthys parvulus Eastman, 1908, a gnathorhizid dipnoan from the Middle Pennsylvanian of Illinois, U.S.A. -Annals of the Carnegie Museum 63 (2): 105-113.

1994. The lungfish Sagenodus (Dipnoi, Osteichthyes) from the Upper Rotliegend (Lower Permian) of the Saar-Nahe Basin, SW-Germany. In Heidtke, U. (Comp.). New Results on Permocarboniferous Fauna. - Pollichia - Buch 29: 125-132 (for 1993).

1994. Rhizodopsis hanbuchi n. sp., a new rhizodopsid rhipidistian (Sarcopterygii, Osteichthyes) from the Lower Rotliegend (Lower Permian) of Palatinate, SW-Germany. In Heidtke, U. (Comp.), New Results on Permocarboniferous Fauna. Pollichia - Buch 29: 133-142 (for 1993). (With U. Heidtke)

1995. The origin of tetrapods - Past and present hypotheses. - Vertebrata PalAsiatica 33 (4): 249-260. (In Chinese and English).

1996. An eugeneodontid elasmobranch from the Late Paleozoic of Kansas. - Journal of Paleontology 70: 162-165. (With R. R. West)

1996. Terrestrial biota in coastal marine deposits: Fossil-Lagerstätten in the Pennsylvanian of Kansas, USA. - Palaeogeography, Palaeoclimatology, Palaeoecology 119: 255-273.

1996. The lungfish Tranodis and the tetrapod fauna from Upper Mississippian deposits of North America. - Special Papers in Palaeontology 52: 31-54. (With J. R. Bolt)

1996. The vertebrates of the Escuminac Formation. In Schultze, H.-P. \& Cloutier, R. (eds). Devonian Fishes and Plants of Miguasha, Quebec, Canada: 120-122. Verlag Dr. F. Pfeil, München.

1996. Porolepiform fishes (Sarcopterygii). In Schultze, H.-P. \& Cloutier, R. (eds). Devonian Fishes and Plants of Miguasha, Quebec, Canada: 248-270. Verlag Dr. F. Pfeil, München. (With R. Cloutier)

1996. The elpistostegid fish Elpistostege, the closest the Miguasha fauna comes to a tetrapod. In Schultze, H.-P. \& Cloutier, R. (eds). Devonian Fishes and Plants of Miguasha, Quebec, Canada: 316-327. Verlag Dr. F. Pfeil, München.

1996. Comparison of the Escuminac Formation ichthyofauna with other late Givetian/early Frasnian ichthyofaunas. In Schultze, H.-P. \& Cloutier, R. (eds). Devonian Fishes and Plants of Miguasha, Quebec, Canada: 348-368. Verlag Dr. F. Pfeil, München. (With R. Cloutier)

1996. Vinctifer (Pisces, Aspidorhynchidae) aus der Unterkreide (oberes Aptium) von Kolumbien. - Neues Jahrbuch für Geologie und Paläontologie, Abhandlungen 119 (3): 395-415. (With D. Stöhr)

1996. The scales of Mesozoic actinopterygians. In Arratia, G. \& Viohl, G. (eds). Mesozoic Fishes - Systematics and Paleoecology: 83-93. Verlag Dr. F. Pfeil, München.

1996. Unterdevonische Fischfunde aus Sedimenten des Flachmeerbereiches der kanadischen Arktis. - Neues Jahrbuch für Geologie und Paläontologie, Abhandlungen 201: 33-93. (With F. Langenstrassen)

1996. Walter R. Gross, a palaeontologist in the turmoil of 20th Century Europe. - Modern Geology 20: 209-233.

1996. Conodont histology: An indicator of vertebrate relationships? - Modern Geology 20: 275-286.

1996. (Obituary of:) Karl F. Hirsch (1921-1996). - Society of Vertebrate Paleontology, News Bulletin 168: 70-72.

1996. (Obituary of:) Dr. h. c. Karl F. Hirsch. 20. 3. 1921-1. 6. 1996 (ein untypischer Lebenslauf eines deutschen Wissenschaftlers). - Paläontologie aktuell H. 34: 1-4. (With R. Kohring \& A. Broschinski)

1996. Kolloquium anlässlich des 100. Todestages von AUGUST HEINRICH BEYRICH am 9. Juli 1996. - Brandenburger Geowissenschaftliche Beiträge 3 (1): 153-154. Kleinmachnow.

1997. Dr. h.c. G. Schaumberg als Paläontologe. In Kreisstadt Eschwege (Hrsg.). Günther Schaumberg. Maler, Kunsterzieher und Paläontologe aus Eschwege zum 75. Geburtstag am 28: 49-57. Eschwege. 
1997. The Permo-Carboniferous genus Sagenodus and the beginning of modern lungfish. - Contributions to Zoology 67 (1): 9-70. (With J. Chorn)

1997. Umweltbedingungen beim Übergang von Fisch zu Tetrapode. - Sitzungsberichte der Gesellschaft der Naturforschenden Freunde zu Berlin, (N.F.) 36: 59-77.

1997. The oldest sarcopterygian fish. - Lethaia 30: 293-304. (With Zhu Min)

1998. The Fossil Record of the Intertidal Zone. In Horn, M. H., Martin K. L. M. \& Chotkowski, M. A. (eds). Intertidal Fishes. Life in Two Worlds: 373-392. Academic Press, San Diego, London, etc.

1998. Sarcopterygian Fishes from the Upper Devonian of Colorado, U.S.A. - Mitteilungen aus dem Museum für Naturkunde in Berlin. Geowissenschaftliche Reihe 1: $53-72$. (With J. Chorn)

1998. Tendaguru-Treffen. - Paläontologie aktuell H. 37: 57-59.

1998. (Review of:) The fossil fauna of Mazon Creek. - Contribution to Zoology 67: 277-279.

1998. Preface. - Mitteilungen aus dem Museum für Naturkunde in Berlin. Geowissenschaftliche Reihe 1: 3-4.

1999. Mesozoic fishes from Chile. In Arratia \& Schultze (eds). Mesozoic Fishes 2 - Systematics and Fossil Record: 565-593. Verlag Dr. Pfeil, München. (With G. Arratia)

1999. Semionotiform fish from the Upper Jurassic of Tendaguru, Tanzania. - Mitteilungen aus dem Museum für Naturkunde in Berlin, Geowissenschaftliche Reihe 2: 135-153. (With G. Arratia)

1999. Body size and body volume distribution in two sauropods from the Upper Jurassic of Tendaguru. - Mitteilungen aus dem Museum für Naturkunde in Berlin, Geowissenschaftliche Reihe 2: 91-102. (With H.-Chr. Gunga, K. Kirsch, J. Rittweger, L. Röcker, A. Clarke, J. Albertz, A. Wiedemann, S. Mokry, T. Suthau, A. Wehr \& W.-D. Heinrich)

1999. Die Fische der Germanischen Trias. In Hauschke, N. \& Wilde, V. (eds). Trias. Eine ganz andere Welt. Mitteleuropa im frühen Erdmittelalter: 239-250. Verlag Dr. F. Pfeil, München. (With J. Kriwet)

1999. (Biography of:) Denison, Robert, Howland - American, 1911-85. In Springer, R. (ed.), Encyclopedia of Paleontology, Vol. 1, A-L: 357-358. Fritzroy Dearborn Publisher, Chicago, London.

1999. (Biography of:) Gross, Walter Robert - Latvian/German, 1903-74. In Springer, R. (ed.). Encyclopedia of Paleontology, Vol. 1, A-L: 537-539. Fritzroy Dearborn Publisher, Chicago, London.

1999. (Obituary of:) Hans L. Jessen (1935-1999). - Paläontologie aktuell 40: 18.

1999. Sarcopterygians. In Springer, R. (ed.). Encyclopedia of Paleontology, Vol. 2, M-Z: 1037-1046. Fritzroy Dearborn Publisher, Chicago, London.

2000. A possible agnathan plate from the Lower Arenig (Lower Ordovician) of South Bolivia. - Journal of Vertebrate Paleontology 20: 394-399. (With B.-D. Erdtmann, B. Weber \& S. Egenhoff)

2000. A porolepiform rhipidistian from the Lower Devonian of the Canadian Arctic. - Mitteilungen aus dem Museum für Naturkunde in Berlin, Geowissenschaftliche Reihe 3: 99-109.

2000. (Field guide:) The Red Hill Locality, Northern Simpson Park Range, Nevada. In $9^{\text {th }}$ International Symposium Early Vertebrates/Lower Vertebrates, Flagstaff, Arizona, Field Guide: 6 pp.

2000. Frühe Knochenfische. Eine Expedition in the kanadische Arktis. - Theatrum naturae 1: 24-25.

2000. Weltnaturerbe Grube Messel. Das Land Hessen zeigt seine Funde aus dem Pompeji der Paläontologie. - Theatrum naturae 1: 26-29. (With W.-D. Heinrich)

2001. Die Geschichte des Lebens erzählt man nicht an einem Abend. - Theatrum naturae: 2. (With G. Scholtz)

2001. Interrelationships of basal osteichthyans. In Ahlberg, P. E. (ed.). Major Events in Early Vertebrate Evolution. Palaeontology, Phylogeny and Development. - Systematics Association Special Volume Series 61: 289-314. Taylor \& Francis, New York. (With Zhu Min)

2001. Dialipina and the character of basal actinopterygians. In Ahlberg, P. E. (ed.). Major Events in Early Vertebrate Evolution. Palaeontology, Phylogeny and Development. - Systematics Association Special Volume Series 61: 315-332. Taylor \& Francis, New York. (With S. L. Cumbaa)

2001. Fossile Knochenfische in der Philatelie. - Fossilien 2001, H.4: 240-247. (With O. Hampe)

2001. Vertebral column and associated elements in dipnoans and comparison with other fishes. Development and homology. - Journal of Morphology 250 (2): 101-172. (With G. Arratia \& J. Casciotta)

2001. Melanognathus, a primitive dipnoan from the Lower Devonian of the Canadian Arctic and the interrelationships of Devonian dipnoans. - Journal of Vertebrate Paleontology 21 (4): 781-794.

\section{Books}

Handbook of Paleoichthyology:

1978. Vol. 2 (Denison, R.: Placodermi). 128 pp., Fischer Verlag, Stuttgart (Schultze, H.-P., ed.). Editor's Preface.

1979. Vol. 5 (Denison, R.: Acanthodi), 62 pp., Fischer Verlag, Stuttgart (Schultze, H.-P., ed.). Editor's Preface.

1981. Vol. 2, 3A (Zangerl, R.: Chondrichthyes I). 115 pp., Fischer Verlag, Stuttgart (Schultze, H.-P., ed.). Editor's Preface.

1985. Vol. 10 (Nolf, D.: Otolithi piscium). 145 pp., Fischer Verlag, Stuttgart (Schultze, H.-P., ed.). Editor's Preface.

1987. Vol. 2, 3B (Cappetta, H.: Chondrichthyes II).193 pp., Fischer Verlag, Stuttgart (Schultze, H.-P., ed.). Editor's Preface.

1999. Vol. 4 (Stahl, B.: Chondrichthyes III, Holocephali). 164 pp., Verlag Dr. F. Pfeil, München (Schultze, H.-P., ed.). Editor's Preface.

1991. Origins of the higher groups of tetrapods. Controversy and Consensus. $724 \mathrm{pp}$ Cornell University Press, Ithaca, New York. (Schultze, H.-P. \& Trueb, L., eds).

1992. Dipnoi. - Fossilium Catalogus. I: Animalia. Pars 131. 464 pp. Kugler Publications, Amsterdam/New York.

1996. Devonian Fishes and Plants of Miguasha, Quebec, Canada. 374 pp. Verlag Dr. F. Pfeil, München. (Schultze, H.-P. \& Cloutier, R., eds).

1996. Mesozoic Fishes 2 - Systematics and Fossil Record. 604 pp., Verlag Dr. Pfeil, München. (Arratia, G. \& Schultze, H.-P., eds). 